Mar. Freshwater Res., 1995, 46, 853-60

\title{
Short- and Long-term Movement Patterns of Six Temperate Reef Fishes (Families Labridae and Monacanthidae)
}

\author{
Neville S. Barrett \\ Zoology Department, University of Tasmania, GPO Box 252C, Hobart, Tas. 7001, Australia.
}

\begin{abstract}
Movement patterns were studied on a 1-ha isolated reef surrounding Arch Rock in southern Tasmania. Short-term movements were identified from diver observations, and interpretation of long-term movements involved multiple recaptures of tagged individuals. Visual observations indicated that the sex-changing labrids Notolabrus tetricus, Pictilabrus laticlavius and Pseudolabrus psittaculus were all site-attached, with females having overlapping home ranges and males being territorial. In the non-sex-changing labrid Notolabrus fucicola and in the monacanthids Penicipelta vittiger and Meuschenia australis, there was no evidence of territorial behaviour and 1-h movements were in excess of the scale of the study. The long-term results indicated that all species were permanent reef residents, with most individuals of all species except $M$. australis always being recaptured within a home range of $100 \mathrm{~m} \times 25 \mathrm{~m}$ or less. Only $15 \%$ of individuals of $M$. australis were always recaptured within this range category. The natural habitat boundary of open sand between the Arch Rock reef and adjacent reefs appeared to be an effective deterrent to emigration. The use of natural boundaries should be an important consideration in the design of marine reserves where the aim is to minimize the loss of protected species to adjacent fished areas.
\end{abstract}

\section{Introduction}

Most tropical reef fishes are now regarded as sedentary, remaining in association with small areas of reef for most of their life (Ehrlich 1975; Sale 1991), on the basis of results of both tagging studies (Randall 1962; Bohnsack 1990) and direct observations made on individual fish with the aid of SCUBA (Reese 1973; Thresher 1979). For these sedentary species, the scale of their daily movements within the reef may range from several metres in a small territorial species, (Sale 1971) to several kilometres in species involved in either cross-reef spawning migrations (Johannes 1978) or migration from sleeping to feeding sites (Hobson 1972). As well as differences between species, there can also be considerable intra-specific variation in range size, with home ranges tending to increase in proportion to the size of individuals (Sale 1978) and in inverse proportion to habitat quality (Matthews 1990). Intra-specific behavioural factors may also significantly influence spatial relationships (Ogden and Buckman 1973).

Most temperate reef fishes may be sedentary as well; however, few studies are available for direct parallels to be drawn between the movement patterns of fishes on temperate and coral reefs, primarily owing to the difficulties associated with using SCUBA in colder waters with low visibility. From the limited number of temperate studies conducted so far, families of temperate reef fishes found during behavioural studies to have site-attached representatives include labrids (Jones 1984), cheilodactylids (Leum and Choat 1980) and pomacentrids (Clarke 1970; Moran and Sale 1977; Norman and Jones 1984). In tagging studies, families found to display site attachment include the rockfishes (Matthews 1990), surfperch, labrids and pomacentrids (Davis and Anderson 1989), and bass (Davis and Anderson 1989; Parker 1990; Low and Waltz 1991). As the study of Davis and Anderson (1989) selected four common Californian reef fishes from different families and trophic positions, and all were site attached, this may indicate a general trend towards site attachment in temperate species, regardless of family or trophic position. However, it is possible that the tendency for year-round residency may decrease with increasing latitude, because some temperate regions experience large seasonal variation in water temperature, forcing reef residents into deeper offshore waters to avoid environmental extremes (Parker 1990) or causing them to hide in a state of torpor (Olla et al. 1979).

The major aim of this study was to further extend the 
limited knowledge of short- and long-term movement patterns of temperate reef fishes, as the movement patterns of even the most common southern Australian reef fishes have not been described. A second aim of this study was to assess the ability of natural habitat boundaries to constrain such movements. An understanding of factors such as these is essential for the design of marine reserves on temperate reefs as well as for proper management of fisheries targeting reef species. The species selected for study are some of the most common fishes in southern Tasmanian waters and include four species of labrids and two species of monacanthids.

\section{Materials and Methods}

\section{Study Site and Species}

The study was conducted on a reef of 1 ha surrounding Arch Rock in southern Tasmania, Australia, and at an adjacent reef at Ninepin Point $1 \mathrm{~km}$ away (Fig. 1). The habitat at Arch Rock is characterized by the macroalgae Durvillea potatorum and Lessonia corrugata in the sublittoral zone, by the macroalgae Macrocystis pyrifera, Ecklonia radiata and Sargassum fallax from 2 to $10 \mathrm{~m}$ depth, and by a carpet of predominantly red algae at $10 \mathrm{~m}$ depth. Sea temperatures range from $8^{\circ} \mathrm{C}$ to $18^{\circ} \mathrm{C}$ during the year. The reef extends from the intertidal to a depth of 7-10 m, with an average offshore extension of $20 \mathrm{~m}$, and completely surrounds the island, which has a circumference of $320 \mathrm{~m}$. This reef is isolated from the nearest adjacent reef by a $1-\mathrm{km}$ stretch of sand, average depth $15 \mathrm{~m}$, which is barren during winter but colonized by red algae during spring and summer. The species studied (Table 1) were the bluethroat wrasse (Notolabrus tetricus), purple wrasse (Notolabrus fucicola), senator wrasse (Pictilabrus laticlavius), rosy wrasse (Pseudolabrus psittaculus), toothbrush leatherjacket (Penicipelta vittiger) and brown-banded leatherjacket (Meuschenia australis). The labrids $N$. tetricus and $N$. fucicola and the monacanthid $P$. vittiger together constitute some of the most abundant shallow-water reef fish in Tasmanian waters, and $P$. laticlavius is abundant in sheltered waters.

\section{Short-term Movements and Observations}

A grid $70 \mathrm{~m} \times 25 \mathrm{~m}$ (5-m squares) was positioned on the reef by means of bricks and rope. This extended from the shoreline to the maximum

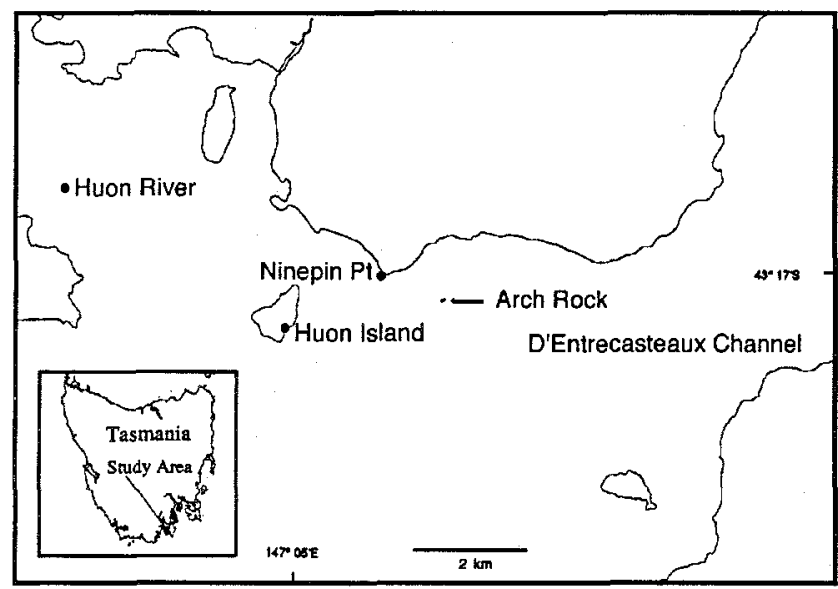

Fig. 1. Lower D'Entrecasteaux Channel region of Tasmania, showing the location of Arch Rock and Ninepin Point. offshore extension of the reef $(20 \mathrm{~m})$ and $5 \mathrm{~m}$ beyond. Attempts to map the home ranges of individually recognized fish failed owing to rapid algal fouling of colour-coded tags attached to the fish for identification. Instead, randomly selected individuals were followed for periods of $1 \mathrm{~h}$ and their movements recorded on a map of the grid printed on waterproof paper. This technique was later modified by recording the fish movements with an underwater video camera (Sony Hi8 mounted in an Amphibico housing) to avoid the loss of fish among the macroalgae while information was being recorded. Estimates of home-range size were derived from the number of $5-\mathrm{m}$ squares entered during a $1 \mathrm{~h}$ period. Behavioural observations, including the frequency of aggressive displays and chases, were used to determine whether home-ranging individuals were territorial. The results were derived from $100 \mathrm{~h}$ of observation over the grid and a further $100 \mathrm{~h}$ over the remaining reef area.

\section{Long-term Movements}

For the long-term study, fish greater than $15 \mathrm{~cm}$ total length were captured in fish traps and each was tagged with a small T-bar tag (Hallprint) inserted at the base of the dorsal fin. Traps were positioned at random on the reef to maximize the possibility of even the most sedentary species encountering a trap during each trapping session, although the reef was arbitrarily divided into 16 sectors (each $20 \mathrm{~m}$ longshore $\times 25 \mathrm{~m}$ offshore) to simplify analysis of movement patterns. Ranges were determined on the basis of the number of sectors in which individuals were recaptured throughout the study. Because the reef had little offshore extension (20-25 $\mathrm{m}$ ) and few fish ever crossed the sand-reef interface, the study was considered to be one-dimensional, with movement around the island being the movement of interest. Initial visual observations of movement indicated that a finer-resolution study in two dimensions was unnecessary as movements in excess of $20 \mathrm{~m}$ were observed in all species.

The nearest adjacent reef, approximately $1 \mathrm{~km}$ away, was searched periodically to identify any individuals migrating between reefs, and tags were printed with a return address to facilitate the return of fish captured by net fishers who intensively gill-net reefs near Arch Rock during the summer months. The study site itself was protected for the duration of the study by a temporary Government ban on net fishing.

Fish were tagged and recaptured over a 2.5-year period between May 1990 and January 1993, with sampling being on a weekly basis for the first nine months and then at three-monthly intervals. Initially, it was intended to gain accurate estimates of population size and emigration and mortality rates from recapture data; however, confounding due to intra-specific behavioural variation, particularly variation in trap response, and insufficient data on tag loss rates precluded this. Fish were not doubletagged to estimate tag loss because of concerns about increased tag-induced mortality. Recapture results were nevertheless used to estimate the net survival rate, which includes loss due to emigration, mortality and tag loss, as this estimate may be of use in assessing rates of emigration in species for which rates of natural mortality and tag loss are known to be small. The method of Fischer and Ford (from Begon 1979) was used as it calculates the average survival rate over the whole recapture period, rather than for individual periods as in the stochastic methods (e.g. Jolly-Seber, from Begon 1979).

The long-term recapture data for each species were analysed by $\chi^{2}$ contingency tables to examine the significance of inter-specific differences in estimated range size and to look for any evidence of length- or sexrelated differences in home-range size. The cells for the contingency tables contained the number of fish whose maximum observed range fell within each of the range categories of $0-20 \mathrm{~m}, 20-40 \mathrm{~m}, 40-60 \mathrm{~m}, 60-80 \mathrm{~m}$, $80-100 \mathrm{~m},>100 \mathrm{~m}$. Where the number in any cell fell below 5 , adjacent range categories were pooled. Where this was not possible, the number of cells with counts less than 5 were kept below $20 \%$ of all cells. For the length-related comparisons, only two size classes were compared (small: large) and the cut-off point for each class was arbitarily chosen to ensure an even balance of numbers between classes. 
Table 1. Biological characteristics of the species included in the Arch Rock movement study

\begin{tabular}{|c|c|c|c|c|c|c|}
\hline Family & Species & Max. length $(\mathrm{cm})$ & Sexual system & $\begin{array}{c}\text { Sexual } \\
\text { dimorphism? }\end{array}$ & $\begin{array}{c}\text { Sexually } \\
\text { dichromatic? }\end{array}$ & Reference \\
\hline Labridae & Notolabrus tetricus & 45 & Protogynous hermaphrodite & No & Yes & $\begin{array}{l}\text { Russell } \\
\text { (1988) }\end{array}$ \\
\hline Labridae & Nototabrus fucicola & 50 & Gonochorism & No & No & $\begin{array}{c}\text { Russell } \\
\text { (1988) }\end{array}$ \\
\hline Labridae & Pictilabrus laticlavius & 30 & Protogynous hermaphrodite & No & Yes & $\begin{array}{l}\text { Russell } \\
\text { (1988) }\end{array}$ \\
\hline Labridae & Pseudolabrus psittaculus & 25 & Protogynous hermaphrodite & No & Yes & $\begin{array}{l}\text { Last } e t \text { al. } \\
\quad \text { (1983) }\end{array}$ \\
\hline Monacanthidae & Penicipelta vittiger & 32 & Gonochorism & Yes & Yes & $\begin{array}{l}\text { Last et al. } \\
\quad(1983)\end{array}$ \\
\hline Monacanthidae & Meuschenia australis & 30 & Gonochorism & Yes & Yes & $\begin{array}{c}\text { Last } \text { et al. } \\
\quad \text { (1983) }\end{array}$ \\
\hline
\end{tabular}

Table 2. Results of $200 \mathrm{~h}$ of behavioural observations on six temperate reef fishes at Arch Rock, Tasmania Range estimates were derived from $(N)$ individuals, each followed for $1 \mathrm{~h} . \quad-$, not applicable (for species in which the males are territorial)

\begin{tabular}{llcccc}
\hline Species & Sex & Number $(N)$ & Estimated range & Territorial? & Home-ranging? \\
\hline Notolabrus & Male & 3 & $400-775 \mathrm{~m}^{2}$ & Yes & - \\
tetricus & Female & 5 & $225-725 \mathrm{~m}^{2}$ & No & Yes \\
Notolabrus & Male & 5 & $>70 \times 25 \mathrm{~m}$ & No & $?$ \\
fucicola & Female & 5 & $>70 \times 25 \mathrm{~m}$ & No & $?$ \\
Pictilabrus & Male & 1 & $175 \mathrm{~m}^{2}$ & Yes & - \\
$\quad$ laticlavius & Female & 0 & $?$ & $?$ & $?$ \\
Pseudolabrus & Male & 2 & $280-330 \mathrm{~m}^{2}$ & Yes & - \\
psittaculus & Female & 3 & $325-375 \mathrm{~m}^{2}$ & No & Yes \\
Penicipelta & Male & 5 & $?$ & No & $?$ \\
vittiger & Female & 5 & $?$ & No & $?$ \\
Meuschenia & Male & 5 & $>70 \times 25 \mathrm{~m}$ & No & $?$ \\
australis & Female & 5 & $>70 \times 25 \mathrm{~m}$ & No & $?$ \\
\hline
\end{tabular}

\section{Short-term Movements}

\section{Results}

The results of the short-term movement observations are summarized in Table 2.

Notolabrus tetricus. Maps of movement during $1 \mathrm{~h}$ were compiled for both females and males; these indicated that all size ranges were active within a home range, swimming almost continuously and covering most of the area within their range during this period. Female home ranges were estimated to range from 225 to $725 \mathrm{~m}^{2}$, extending over the depth range of the reef and usually overlapping those of many other females and two to three males. Although there were frequent displays of aggression between juveniles and between females, there was no evidence of territorial defence by either group. Males were highly territorial and patrolled clearly defined ranges, with any intrusion by a neighbouring male instigating a chase. The three males, whose territory overlapped the study grid, had estimated territorial ranges of $400-775 \mathrm{~m}^{2}$. During the spawning season (September to January), males continuously courted the females within their territory, displaying with a raised caudal fin as they passed each female.

Notolabrus fucicola. All individuals whose movements were mapped ranged freely over the entire grid $(70 \mathrm{~m} \times 25 \mathrm{~m}$ ) during a 1-h period. Over the duration of the study, several distinctly marked individuals were seen on numerous occasions and on all sectors of the reef, indicating that at least some individuals had ranges equal to, or in excess of, 1 ha. Although males were frequently involved in chases during the breeding season (late August to January), there was no evidence of territorial behaviour, with males and females occupying continuously overlapping home ranges. Males constantly followed females during this time, occasionally displaying to them with raised dorsal and anal fins, until either being chased off by another male or swapping to follow another female. 
Pictilabrus laticlavius. The cryptic coloration of juvenile and female fish made them difficult to see, and this, combined with their habit of hiding among the algal canopy, prevented a detailed study of short-term movements in this species. Observations of males in their spawning season (September to January) indicated that they may be territorial as frequent chases were observed, and one male observed for $1 \mathrm{~h}$ actively patrolled a home range of $175 \mathrm{~m}^{2}$, chasing off all male intruders and courting females.

Pseudolabrus psittaculus. In this species, females actively swam within overlapping home ranges of approximately $325-375 \mathrm{~m}^{2}$, which were restricted to the deeper parts of the reef $(5-10 \mathrm{~m})$, whereas males were territorial with estimated ranges of $280-330 \mathrm{~m}^{2}$, chasing off any male intruders. During the spawning season (September to January), males regularly displayed to the females within their territory with a raised caudal fin.

Penicipelta vittiger. Although many adult fish were present over the grid, their behaviour limited meaningful observation because while feeding on their primary food source (epiphytic invertebrates), individuals rarely moved for periods in excess of $1 \mathrm{~h}$, except to adjacent plants. When mobile, individuals crossing the observation grid displayed no evidence of site attachment at this scale or of territorial behaviour. During the spawning season (September to January), males constantly followed females until either swapping to another female or being involved in a chase with another male, with the chase usually resulting in both males losing contact with the female.

Meuschenia australis. Short-term movements of both sexes were on a scale larger than the grid, and there was no evidence of site attachment at that scale. Males and females shared broadly overlapping home ranges and there was no indication of territorial behaviour by either sex. During the mating season (September to January), males were often seen following females for extended periods. Interactions between males were infrequently observed, possibly owing to the low population density of this species.

\section{Long-term Movements}

Over a period of 2.5 years, 1294 fish were tagged on the reef surrounding Arch Rock, and 2601 recaptures were recorded. During this time, extensive diving surveys of the adjacent reef systems at Ninepin Point failed to detect any immigrants from Arch Rock, although two $P$. vittiger individuals were captured by recreational fishers. One of these had travelled $1.5 \mathrm{~km}$, the other $4.5 \mathrm{~km}$, with both movements from Arch Rock involving the crossing of extensive areas of open sandy bottom.

Annual loss rates calculated from recapture data by the method of Fischer and Ford (from Begon 1979) gave an indication of the rates of emigration for species where mortality and tag loss rates were low (Table 3 ), as loss is equivalent to emigration plus mortality (including tag loss). In three species (N. tetricus, $N$. fucicola and $M$. australis), annual survivorship was estimated at $100 \%$, which indicates that if any emigration occurs in these species, rates must be low. The unusually high annual survivorship estimate appears to be related to intra-specific variability in trap response. Pictilabrus psittaculus had an estimated annual survivorship of $60 \%$, and although mortality, tag loss and emigration cannot be separated, such a high survivorship still indicates that any emigration must be low. The survivorship estimates for $P$. vittiger $(37 \%)$ and $P$. laticlavius (13\%) were considerably lower than those for the other species and cannot be used as an indication of emigration rates because of confounding with mortality and tag loss. However, these low values probably reflect higher rates of natural mortality and tag loss, because $P$. vittiger was found to be a short-lived species (two to three years) during the course of this study and P. laticlavius was found to have significant rates of tag loss through abrasion due to the close affinity of this species with the substratum.

The long-term home-range patterns estimated from recaptures over a 2.5-year period between May 1990 and January 1993 are shown in Fig. 2, with summary data in Table 4. As all species displayed considerable intra-specific variability in home-range size, the results in Fig. 2 are presented as the cumulative percentage of individuals that were always recaptured within each maximum range. Most

Table 3. Average annual survival rate estimates for six temperate reef fishes at Arch Rock, Tasmania, calculated by the method of Fischer and Ford (from Begon 1979)

\begin{tabular}{lcccccc}
\hline & $\begin{array}{c}\text { Notolabrus } \\
\text { tetricus }\end{array}$ & $\begin{array}{c}\text { Notolabrus } \\
\text { fucicola }\end{array}$ & $\begin{array}{c}\text { Pictilabrus } \\
\text { laticlavius }\end{array}$ & $\begin{array}{c}\text { Pseudolabrus } \\
\text { psittaculus }\end{array}$ & $\begin{array}{c}\text { Penicipelta } \\
\text { vittiger }\end{array}$ & $\begin{array}{c}\text { Meuschenia } \\
\text { australis }\end{array}$ \\
\hline Recapture period & $6 / 90-3 / 91$ & $6 / 90-5 / 91$ & $8 / 90-8 / 91$ & $8 / 90-5 / 91$ & $6 / 90-3 / 91$ & $6 / 90-3 / 91$ \\
Recapture events & 12 & 12 & 7 & 6 & 8 & 12 \\
Number tagged & 278 & 63 & 49 & 53 & 87 & 60 \\
Number of recaptures & 122 & 150 & 19 & 56 & 32 & 170 \\
Estimated survival rate & 1.00 & 1.00 & 0.13 & 0.60 & 0.37 & 1.00 \\
\hline
\end{tabular}


individuals of $N$. tetricus, $N$. fucicola, $P$. laticlavius, $P$. psittaculus and $P$. vittiger were found to have estimated home ranges of less than $100 \mathrm{~m} \times 25 \mathrm{~m}$ during this period, although a significant proportion of $N$. fucicola (43\%) had an estimated range in excess of $100 \mathrm{~m} \times 25 \mathrm{~m}$. The high average numbers of days between first and last capture (Table 4) indicated that these patterns were stable over time and not just the result of short-term residency. Meuschenia australis was the most wide-ranging species, with only $15 \%$ of individuals always being recaptured within a range of 100 $\mathrm{m} \times 25 \mathrm{~m}$ or less.

A pairwise comparison by $\chi^{2}$ of the difference between the range sizes of each species showed all species to be significantly different from each other, at least at the 0.05 significance level (Table 5). The order of range size by species was $P$. laticlavius $<P$. psittaculus $<N$. tetricus $<P$. vittiger $<N$. fucicola $<M$. australis, with the three territorial species having estimated ranges smaller than those of the non-territorial species.

When the long-term recapture results for each species were examined by a $\chi^{2}$ test for sex-related differences in

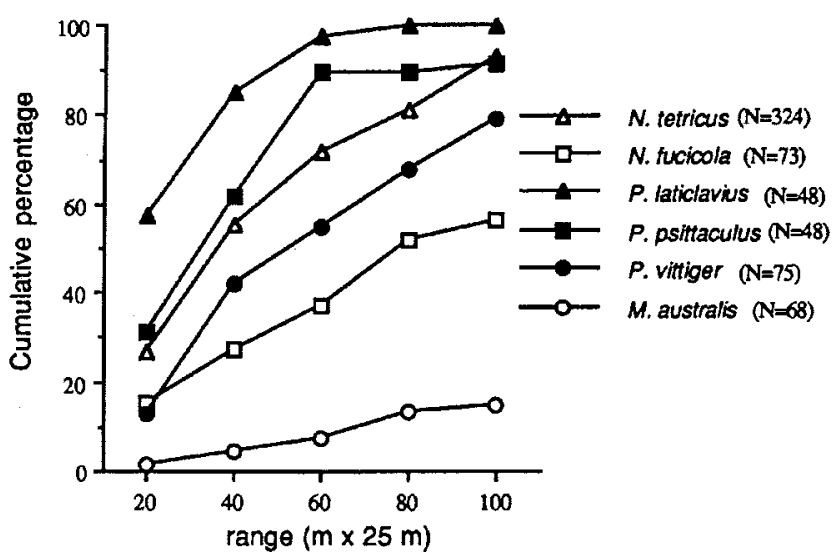

Fig. 2. Intra-specific home-range variation identified from recaptures of tagged fish at Arch Rock, Tasmania, between May 1990 and January 1993. Calculated from the maximum observed ranges of fish recaptured at least once and plotted as the cumulative percentage of individuals always recaptured within a range equal to or less than the range shown. home-range size, none were detected (Table 6). The results were then examined by a $\chi^{2}$ test for length-related differences in home-range size (Table 7). In four species $(N$. tetricus, $P$. laticlavius, $P$. psittaculus and $M$. australis), length was significantly related to range size, with ranges increasing with length. The failure to detect any relationship between range size and length in $N$. fucicola and $P$. vittiger may be due more to the lack of small $(15-20 \mathrm{~cm})$ fish tagged and recaptured than to the absence of a relationship.

The labrid species are almost certainly permanent residents of the study reef as no immigrants were detected during extensive surveys of adjacent reefs and no tags were returned from local fishers. This observation is in addition to the low estimated mortality rates for $N$. tetricus, $N$. fucicola and $P$. psittaculus, which indicate that any loss due to emigration must low (Table 3), and to the high average numbers of days between first and last capture for all of these species (Table 5).

Although short-term visual observations on the monacanthid species $P$. vittiger and $M$. australis failed to identify any clear patterns of spatial use, the long-term recapture data provide some indications. Penicipelta vittiger displayed the stronger tendency for site attachment, with $79 \%$ of recaptured individuals always being recaptured within a range of $100 \mathrm{~m} \times 25 \mathrm{~m}$ or less. With a moderate recapture rate (35\% recaptured at least once) and a high average number of days between first and last capture (178 days), it appears likely that the majority of individuals are permanent residents of the reef. Recapture rates and numbers of days between first and last capture may be lower than those estimated for the labrid species and $M$. australis as a result of the comparatively short life span of $P$. vittiger (Barrett, unpublished data). Although two tag returns from local fishers indicate that this species can move considerable distances (1.5 and $4.5 \mathrm{~km}$ ) and across major habitat boundaries, it is likely that these individuals represent only a small percentage of the population. Extensive searches of adjacent reefs found no evidence of immigrant $P$. vittiger, which would have been expected if emigration rates were higher.

Table 4. Summary data of the movements of six species of temperate reef fish at Arch Rock, Tasmania Derived from a 2.5-year recapture study between May 1990 and January 1993

\begin{tabular}{lcccccc}
\hline Species & Captures & Recaptures & $\begin{array}{c}\text { Mean } \\
\text { recaptures } \\
\text { per individual }\end{array}$ & $\begin{array}{c}\text { Highest } \\
\text { recaptures } \\
\text { per individual }\end{array}$ & $\begin{array}{c}\text { Percentage } \\
\text { recaptured at } \\
\text { least once }\end{array}$ & $\begin{array}{c}\text { Average days } \\
\text { between first } \\
\text { and last capture }\end{array}$ \\
\hline Notolabrus tetricus & 612 & 644 & 1.1 & 14 & 53 & 287 \\
Notolabrus fucicola & 103 & 588 & 5.7 & 43 & 71 & 370 \\
Pictilabrus laticlavius & 183 & 90 & 0.5 & 8 & 26 & 249 \\
Pseudolabrus psittaculus & 85 & 155 & 1.8 & 11 & 56 & 398 \\
Penicipelta vittiger & 214 & 170 & 0.8 & 22 & 35 & 178 \\
Meuschenia australis & 97 & 954 & 9.8 & 46 & 70 & 402 \\
\hline
\end{tabular}


Table 5. Results of pairwise comparisons by $\chi^{2}$, based on contingency tables derived from the long-term recapture results, of the home-range sizes of six temperate reef fishes $\left(H_{0}\right.$ : range of Species 1 equal to range of Species 2$)$ Results are given as probability, and in parentheses, degrees of freedom

\begin{tabular}{llllll}
\hline Species & $\begin{array}{c}\text { Notolabrus } \\
\text { tetricus }\end{array}$ & $\begin{array}{c}\text { Notolabrus } \\
\text { fucicola }\end{array}$ & $\begin{array}{c}\text { Pictilabrus } \\
\text { laticlavius }\end{array}$ & $\begin{array}{c}\text { Pseudolabrus } \\
\text { psittaculus }\end{array}$ & $\begin{array}{c}\text { Penicipelta } \\
\text { vittiger }\end{array}$ \\
\hline $\begin{array}{l}\text { Notolabrus fucicola } \\
\text { Pictilabrus laticlavius }\end{array}$ & $0.0001(5)$ & & & & \\
Pseudolabrus psittaculus & $0.0001(5)$ & $0.0001(3)$ & & & \\
Penicipelta vittiger & $0.046(3)$ & $0.0001(3)$ & $0.025(3)$ & & \\
Meuschenia australis & $0.0015(5)$ & $0.025(4)$ & $0.0001(3)$ & $0.0003(3)$ & $0.0001(2)$ \\
\hline
\end{tabular}

Table 6. Results of $\chi^{2}$ tests, based on contingency tables derived from the long-term recapture results, of the influence of sex on the home-range size of six temperate reef fishes $\left(H_{0}\right.$ : range of males equal to range of females)

\begin{tabular}{lccccc}
\hline Species & $(N)$ & Sex ratio $(\mathrm{M}: \mathrm{F})$ & $\begin{array}{c}\text { Degrees of } \\
\text { freedom }\end{array}$ & Significance level $(P)$ & $\begin{array}{c}\text { Significant } \\
\text { result }(\mathrm{Y} / \mathrm{N})\end{array}$ \\
\hline Notolabrus tetricus & 324 & $13.1: 1$ & 2 & 0.92 & $\mathrm{~N}$ \\
Notolabrus fucicola & 66 & $2.5: 1$ & 1 & 0.16 & $\mathrm{~N}$ \\
Pictilabrus laticlavius & 48 & $1: 2.0$ & 1 & 0.87 & $\mathrm{~N}$ \\
Pseudolabrus psittaculus & 48 & $5.9: 1$ & 1 & 0.98 & $\mathrm{~N}$ \\
Penicipelta vittiger & 61 & $1.4: 1$ & 2 & 0.82 & $\mathrm{~N}$ \\
Meuschenia australis & 68 & $1.22: 1$ & 1 & 0.46 & $\mathrm{~N}$ \\
\hline
\end{tabular}

Table 7. Results of $\chi^{2}$ tests, based on contingency tables derived from the long-term recapture results, of the influence of fish length on the home-range size of six temperate reef fishes $\left(H_{0}:\right.$ range of small equal to range of large, $H_{1}:$ range of small less than range of large)

\begin{tabular}{lccccc}
\hline Species & $(N)$ & $\begin{array}{c}\text { Length classes } \\
\text { compared }(\mathrm{cm})\end{array}$ & $\begin{array}{c}\text { Degrees of } \\
\text { freedom }\end{array}$ & Significance level $(P)$ & $\begin{array}{c}\text { Significant }) \\
\text { result (Y/N }\end{array}$ \\
\hline Notolabrus tetricus & 257 & $15-20: 20+$ & 2 & 0.044 & $\mathrm{Y}$ \\
Notolabrus fucicola & 74 & $15-25: 25+$ & 1 & 0.50 & $\mathrm{~N}$ \\
Pictilabrus laticlavius & 47 & $15-21: 21+$ & 1 & 0.014 & $\mathrm{Y}$ \\
Pseudolabrus psittaculus & 45 & $15-20: 20+$ & 1 & 0.018 & $\mathrm{Y}$ \\
Penicipelta vittiger & 63 & $19-25: 25+$ & 2 & 0.090 & $\mathrm{~N}$ \\
Meuschenia australis & 67 & $15-21: 21+$ & 1 & 0.0002 & $\mathrm{Y}$ \\
\hline
\end{tabular}

For $M$. australis, the long-term recapture data indicated that only a small proportion of individuals were always recaptured within a range of $100 \mathrm{~m} \times 25 \mathrm{~m}$ or less (Fig. 1). Although a study over larger spatial scales is needed to determine whether most individuals are home-ranging, the results of the present study suggest that most individuals were at least permanent residents of the reef. This is indicated by the high average number of days between first and last capture (402 days), the very high proportion recaptured at least once (70\%), and the annual survivorship estimate of $100 \%$.

\section{Discussion}

The short- and long-term movement patterns of the labrid species observed during this study appear similar to those described for other temperate labrids such as Pseudolabrus celidotus, reported by Jones (1984), and fall within the range of behaviours described for labrids in general (Thresher 1984). Notolabrus tetricus, Pictilabrus laticlavius and Pseudolabrus psittaculus are site-attached protogynous hermaphrodites, where females have widely overlapping home ranges and males are territorial, at least during the breeding season, excluding all other males from their range. Notolabrus fucicola is unusual in that it is not hermaphroditic, although a similar sexual system has now been described in three northern European labrids (Costello 1991) and this sexual system may be more common than previously thought, at least in temperate regions. However, compared with the northern European labrids, where males are territorial (Costello 1991), the social system of $N$. fucicola is more similar to that of the Caribbean species Halichoeres garnoti, described by Thresher (1979), where spawning is promiscuous and home ranges are broadly overlapping. 
Behavioural observations indicated that both monacanthid species displayed no evidence of territorial behaviour, with many individuals having overlapping ranges. This contrasts with the territorial behaviour reported by Barlow (1987) for large individuals of a tropical monacanthid species, the longnose filefish (Oxymonacanthus longirostris), and with that of several species in the related family Balistidae, including the tropical species Odonus niger and Pseudobalistes fuscus reported by Fricke (1980) and Sufflamen verres reported by Thresher (1984). As the monacanthids are predominantly a temperate family and observation-based temperate research is generally limited by cold water with low visibility, there are few published descriptions of their behaviour and more studies are needed before a general understanding of their typical movement patterns emerges.

As the long-term movement results indicated considerable intra-specific variation in range size, the results were examined to determine the relative importance of sex and size in explaining this variation. Range size was not found to be sex-related in any of the species examined, although it was found to increase in proportion to the size of individuals in four of the six species. This size-related relationship has been described in tropical species (Sale 1978) and at least one other temperate species (Jones 1984) and is likely to apply to most resident species on both temperate and tropical reefs.

Regardless of sexual systems and behaviour, all six species appeared to be permanent residents of the reef and therefore the results of this study on common Southern Hemisphere temperate reef fishes are comparable to those of Davis and Anderson (1989) on common Northern Hemisphere temperate reef fishes, suggesting a general trend for long-term site attachment in many reef species, a result previously described for tropical reef fishes (Ehrlich 1975). This result is not unexpected as familiarity with a section of reef offers many advantages such as an intimate knowledge of feeding, sleeping and shelter sites, and these advantages would not be expected to differ substantially between tropical and temperate reefs.

Unlike in some temperate regions where environmental extremes force offshore movements (Parker 1990) or hiding and torpor (Olla et al. 1979), all species in the present investigation remained present and active throughout the year, probably because of the small seasonal water temperature variation of $8-18^{\circ} \mathrm{C}$ at Arch Rock compared with that described by Parker (1990) for North Carolina $\left(6-28^{\circ} \mathrm{C}\right)$. As large seasonal water temperature variations have not been reported for southern Australia, it is likely that the results from this study can be extended to other sites and species, suggesting a general trend for year-round residency in the southern Australian reef fish fauna.

The natural habitat boundary of $1 \mathrm{~km}$ of open sandy bottom between the study site and the nearest adjacent reef system appeared to severely restrict the movement of post-recruitment reef fish. There was no evidence of emigration across this boundary by the labrids and only limited evidence of emigration of monacanthid residents, even though some individuals of $N$. fucicola and $P$. vittiger were known to range over the entire reef on a daily basis. The $4.5-\mathrm{km}$ movement recorded for one $P$. vittiger does indicate that movements across boundaries and over long distances are possible, but this is likely to be restricted to a small percentage of the population, and similar intraspecific variability in behaviour has been recorded in several tropical species (Bohnsack 1990).

The effectiveness of natural habitat boundaries in preventing emigration, and the long- and short-term scales of movement in resident fishes, should be important considerations in the future design and management of marine reserves on temperate reefs where protection of local fish populations is desired. This is especially the case for small reserves such as the Ninepin Point and Bicheno reserves in Tasmania, where the core protected area consists of only $1 \mathrm{~km}$ of coastline. Species such as $N$. fucicola and $M$. australis are capable of daily movements of at least 180 $\mathrm{m}$ in one dimension, and 10 -min movements of $230 \mathrm{~m}$ have been reported by Leum and Choat (1980) for Cheilodactylus spectabilis, another common temperate reef resident. These movements imply that a significant proportion of some species may range outside of a small $(1 \mathrm{~km})$ reserve as part of their normal daily behaviour and be subject to fishing mortality. To address this problem, the minimum reserve diameter should be at least an order of magnitude greater than the daily movements of the most wide-ranging residents in order to minimize losses. Where the creation of appropriately sized reserves is not possible, sites should be selected where natural habitat boundaries can be used to isolate the reserve from adjacent areas, effectively fencing in the protected population.

\section{Acknowledgments}

This work was supported by an Australian Postgraduate Research Award scholarship. Thanks go to Peter Davies and Alex Schaap for donating fish tags and tagging guns, and to Robert White and Grahame Edgar for reviewing the manuscript, and to the three referees whose comments helped to improve the paper significantly.

\section{References}

Barlow, G. W. (1987). Spawning, eggs and larvae of the longnose filefish Oxymonacanthus longirostris, a monogamous coralivore. Environmental Biology of Fishes 20, 183-94.

Begon, M. (1979). 'Investigating Animal Abundance: Capture-Recapture for Biologists.' (Arnold: London.)

Bohnsack, J. A. (1990). The potential of marine fishery reserves for reef fish management in the US southern Atlantic. NOAA Technical Memorandum No. 261 
Clarke, T. A. (1970). Territorial behavior and population dynamics of a territorial reef fish, the garribaldi, Hypsypops rubicunda. Ecological Monographs 40, 189-212.

Costello, M. J. (1991). Review of the biology of wrasse (Labridae : Pisces) in northern Europe. Progress in Underwater Science 16, $29-51$.

Davis, G. E., and Anderson, T. W. (1989). Population estimates of four kelp forest fishes and an evaluation of three in situ assessment techniques. Bulletin of Marine Science 44, 1138-51.

Ehrlich, P. R. (1975). The population biology of coral reef fishes. Annual Review of Ecology and Systematics 6, 211-47.

Fricke, H. W. (1980). Mating systems, maternal and biparental care in triggerfish (Balistidae). Zeitschrift für Tierpsychologie 53, 105-22.

Hobson, E. S. (1972). Activity of Hawaiian reef fishes during the evening and morning transitions between daylight and darkness. Fishery Bulletin (US) 70, 715-40.

Johannes, R. E. (1978). Reproductive strategies of coastal marine fishes in the tropics. Evironmental Biology of Fishes 3, 65-84.

Jones, G. P. (1984). The influence of habitat and behavioural interactions on the local distribution of the wrasse, Pseudolabrus celidotus. Environmental Biology of Fishes 10, 43-58.

Last, P. R., Scott, E. O. G., and Talbot, F. H. (1983). 'Fishes of Tasmania.' (Tasmanian Fisheries Development Authority: Hobart.)

Leum, L., and Choat, J. H. (1980). Density and distribution patterns of the temperate marine fish Cheilodactylus spectabalis in a reef environment. Marine Biology (Berlin) 57, 327-33.

Low, R. A., and Waltz, C. W. (1991). Seasonal utilisation and movement of black sea bass on a South Carolina artificial reef. North American Journal of Fisheries Management 11, 131-8.

Matthews, K. R. (1990). An experimental study of the habitat preferences and movement patterns of copper, quillback, and brown rockfishes (Sebastes spp.). Environmental Biology of Fishes 29, 161-78.

Moran, M. J., and Sale, P. F. (1977). Seasonal variation in territorial response, and other aspects of the ecology of the Australian temperate pomacentrid fish Parma microlepis. Marine Biology (Berlin) 39, 121-8.

Norman, M. D., and Jones, G. P. (1984). Determinants of territory size in the pomacentrid reef fish, Parma victoriae. Oecologia (Berlin) 61, 60-9.

Ogden, J. C., and Buckman, N. S. (1973). Movements, foraging groups, and diural migrations in the striped parrotfish Scarus croicensis Bloch (Scaridae). Ecology 54, 589-96.
Olla, B. L., Bejda, A. J., and Martin, A. D. (1979). Seasonal dispersal and habitat selection of cunner, Tautogolabrus adspersus, and young tautog Tautoga onitis, in Fire Island Inlet, Long Island, New York. Fishery Bulletin (US) 77, 255-61.

Parker, R. O. (1990). Tagging studies and diver observations of fish populations on live-bottom reefs of the US southeastern coast. Bulletin of Marine Science 46, 749-60.

Randall, J. E. (1962). Tagging reef fishes in the Virgin Islands. Proceedings of the Annual Session, Gulf and Caribbean Fisheries Institute 1, 201-41.

Reese, E. S. (1973). Duration of residence by coral reef fishes on 'home' reefs. Copeia 1973(1), 145-9.

Russell, B. C. (1988). Revision of the labrid fish genus Pseudolabrus and allied genera. Records of the Australian Museum 9, 1-76.

Sale, P. F. (1971). Extremely limited home-range in a coral reef fish, Dascyllus auranus (Pisces : Pomacentridae). Copeia 1971(2), 324-7.

Sale, P. F. (1978). Reef fishes and other vertebrates: a comparison of social structures. In 'Contrasts in Behavior: Adaptations in the Aquatic and Terrestrial Environments'. (Eds E. S. Reese and F. J. Lighter.) pp. 313-46. (Wiley Interscience: New York.)

Sale, P. F. (1991). Introduction. In 'The Ecology of Fishes on Coral Reefs'. (Ed. P. F. Sale.) pp. 3-15. (Academic Press: London.)

Thresher, R. E. (1979). Social behaviour and ecology of two sympatric wrasses (Labridae : Halichoeres spp.) off the coast of Florida. Marine Biology (Berlin) 53, 161-72.

Thresher, R. E. (1984). 'Reproduction in Reef Fishes.' (TFH Publications: Hong Kong.)

Manuscript received 1 August 1994; revised 7 November 1994; accepted 7 February 1995 